Technological University Dublin

DƯBLIN

ARROW@TU Dublin

Articles

Crest: Centre for Research in Engineering

Surface Technology

2012-02-01

\title{
Preparation and Rapid Analysis of Antibacterial Silver, Copper and Zinc Doped Sol-gel Surfaces
}

\author{
Brendan Duffy \\ Technological University Dublin, brendan.duffy@tudublin.ie \\ Swarna Jaiswal \\ Technological University Dublin, swarna.jaiswal@tudublin.ie \\ Patrick McHale \\ Technological University Dublin, patrick.mchale@tudublin.ie
}

Follow this and additional works at: https://arrow.tudublin.ie/cenresart

Part of the Analytical Chemistry Commons, Materials Chemistry Commons, and the Polymer Chemistry Commons

\section{Recommended Citation}

S. Jaiswal, et al. (2012) Preparation and rapid analysis of antibacterial silver, copper and zinc doped sol-gel surfaces, Colloids Surf. B: Biointerfaces Jun 1;94:170-6 (2012), doi:10.1016/ j.colsurfb.2012.01.035

This Article is brought to you for free and open access by the Crest: Centre for Research in Engineering Surface Technology at ARROW@TU Dublin. It has been accepted for inclusion in Articles by an authorized administrator of ARROW@TU Dublin. For more information, please contact arrow.admin@tudublin.ie, aisling.coyne@tudublin.ie,gerard.connolly@tudublin.ie. Funder: DIT ABBEST

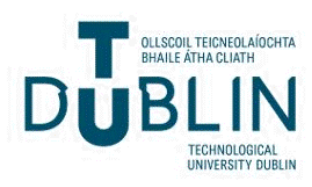




\title{
Preparation and rapid analysis of antibacterial silver, copper and zinc doped sol-gel surfaces
}

\author{
Swarna Jaiswal ${ }^{\mathrm{a}, \mathrm{b}}$, Patrick McHale ${ }^{\mathrm{b}}$, Brendan Duffy ${ }^{\mathrm{a}, *}$ \\ a Centre for Research in Engineering Surface Technology (CREST), FOCAS Institute, Dublin Institute of Technology, Dublin 8, Ireland \\ ${ }^{\mathrm{b}}$ School of Biological Sciences, Dublin Institute of Technology, Kevin Street, Dublin 8, Ireland
}

\section{A R T I C L E I N F O}

\section{Article history:}

Received 30 September 2011

Received in revised form

12 December 2011

Accepted 23 January 2012

Available online $\mathrm{xxx}$

\section{Keywords:}

Antibacterial activity

Metal doped sol-gel

Microtitre well coating

\begin{abstract}
A B S T R A C T
The colonisation of clinical and industrial surfaces with microorganisms, including antibiotic-resistant strains, has promoted increased research into the development of effective antibacterial and antifouling coatings. This study describes the preparation of metal nitrate $(\mathrm{Ag}, \mathrm{Cu}, \mathrm{Zn})$ doped methyltriethoxysilane (MTEOS) coatings and the rapid assessment of their antibacterial activity using polyproylene microtitre plates. Microtitre plate wells were coated with different volumes of liquid sol-gel and cured under various conditions. Curing parameters were analysed by thermogravimetric analysis (TGA) and visual examination. The optimum curing conditions were determined to be $50-70^{\circ} \mathrm{C}$ using a volume of $200 \mu$ l. The coated wells were challenged with Gram-positive and Gram-negative bacterial cultures, including biofilm-forming and antibiotic-resistant strains. The antibacterial activities of the metal doped sol-gel, at equivalent concentrations, were found to have the following order: silver > zinc > copper. The order is due to several factors, including the increased presence of silver nanoparticles at the sol-gel coating surface, as determined by X-ray photoelectron spectroscopy, leading to higher elution rates as measured by inductively coupled plasma atomic emission spectroscopy (ICP-AES). The use of microtitre plates enabled a variety of sol-gel coatings to be screened for their antibacterial activity against a wide range of bacteria in a relatively short time. The broad-spectrum antibacterial activity of the silver doped sol-gel showed its potential for use as a coating for biomaterials.
\end{abstract}

(c) 2012 Elsevier B.V. All rights reserved.

\section{Introduction}

Metals such as silver $(\mathrm{Ag})$, gold $(\mathrm{Au})$, copper $(\mathrm{Cu})$ and zinc $(\mathrm{Zn})$ are well known for their antibacterial activities [1] and are used for a number of in vitro and in vivo applications. Silver has been used to prevent bacterial colonisation of prostheses [2], catheters [3], and human skin [4]. In hospitals, copper alloys, used in doorknobs and other surfaces, exerted an in vitro antimicrobial effect against Escherichia coli 0157, methicillin-resistant Staphylococcus aureus (MRSA) and Clostridium difficile while equivalent stainless steel surfaces did not [5-8]. Copper and zinc amalgams have proven useful in dental materials [6] while their salts have been incorporated into mouthwashes for the treatment of gingivitis [9].

The use of coatings with both low surface energies and antibacterial capabilities (via active additives) is an effective strategy for reducing microbial numbers on healthcare surfaces. The low surface energy chemistry minimises microbial attachment while antibacterial additives kill bacteria or inhibit their growth.

\footnotetext{
* Corresponding author. Tel.: +353 14027964.

E-mail address: brendan.duffy@dit.ie (B. Duffy).
}

Moreover, these coatings can be engineered to release the active agents over a prolonged time period.

Antimicrobial agents (inorganic metal ions or organic molecules) can be incorporated into surface coatings by advanced deposition techniques such as vapour deposition, ion implantation, sputtering and electrochemical deposition from solution [10]. However, these technologies (a) can be costly, (b) are not easily applicable to large or complex items, (c) may not adhere sufficiently to the substrate without previous surface treatment and, (d) may lack transparency after application. A promising alternative technique for coating surfaces is the sol-gel method which requires low processing temperatures and produces a coating with high purity and homogeneity. Sol-gels are organic-inorganic hybrid polymers which produce glass-like surfaces with properties analogous to organic coatings. The sol-gel method offers a unique opportunity to incorporate metal components into a pure or organically modified inorganic matrix through a variety of methods such as entrapment, electrostatic interaction, adsorption and covalent binding [11].

In the present work, a coating strategy employing a combination of antibacterially active metal ions and hydrophobic chemistries to protect surfaces against the attachment of ionic precipitates and bacteria was investigated. The synthesis of silver, copper 
and zinc ion doped methyltriethoxy silane (MTEOS) sol-gel, and their characterization by nuclear magnetic resonance (NMR) and thermogravimetric analysis (TGA) is described. A "microtitre well coating proliferation assay", was used to evaluate the activities of these sol-gel coatings against a number of Gram-positive and Gram-negative bacteria and was found to be more rapid and less laborious than the standard JIS Z 2801 method. The surfaces of sol-gel coated glass slides were studied and compared using Xray photoelectron spectroscopy (XPS) and contact angle analysis. The growth of biofilm-forming bacteria on the coated and uncoated glass slides was examined by scanning electron microscopy (SEM). Finally, the release rates of the different metal ions from the coated surfaces were studied and correlated with the efficacy data.

\section{Experimental procedure}

\subsection{Preparation of metal doped methyltriethoxysilane (MTEOS)} sol-gel

Methyltriethoxysilane (MTEOS) (Ger, Aldrich) was hydrolysed under acidic conditions in the presence of the metal nitrate salt of interest. All metal concentrations are presented in percentage $(\%$, $\mathrm{w} / \mathrm{w}$ ) relative to the final coating mass. To prepare stock MTEOS sol-gel, ethanol $(17.5 \mathrm{ml})$ was added to precursor MTEOS $(24 \mathrm{ml})$, followed by the gradual addition of nitric acid ( $3 \mathrm{ml}$ of $0.04 \mathrm{M})$ and water $(7.8 \mathrm{ml})$. This stock solution was stirred for $3 \mathrm{~h}$ and aliquoted ( $3 \mathrm{ml}$ amounts) for doping purposes. Different doping concentrations $[1,0.7,0.5,0.3$ and $0.1 \%(\mathrm{w} / \mathrm{w})]$ of each of the metals $(\mathrm{Ag}, \mathrm{Cu}$, $\mathrm{Zn}$ ) were achieved by direct addition of the corresponding metal nitrate $\left[\mathrm{AgNO}_{3}, \mathrm{Cu}\left(\mathrm{NO}_{3}\right)_{2} \cdot 2 \mathrm{H}_{2} \mathrm{O}\right.$ and $\left.\mathrm{Zn}\left(\mathrm{NO}_{3}\right)_{2} \cdot 6 \mathrm{H}_{2} \mathrm{O}\right]$ (Aldrich) to the sol-gel solutions and stirred continuously for $24 \mathrm{~h}$. A blank (metal free) sol-gel control was also prepared. Glassware containing silver nitrate dopants was wrapped with aluminium foil to prevent photo reduction of the silver ions.

\subsection{Evaluation of sol-gel solutions}

\subsubsection{Nuclear magnetic resonance (NMR) of metal doped sol-gel solutions}

Chemical interaction between the silane matrix and the metal ions were analysed using liquid-state ${ }^{29} \mathrm{Si}$ NMR spectroscopy using a Bruker $400 \mathrm{MHz}$ spectrometer. The method determined the degree of hydrolysis and condensation of the organosilane skeleton structure in each system, as measured by the number of hydroxo and oxo bridges, respectively. Classical $T$ notation was used for the different silicate species depending on the number of oxygen bridging atoms, $i$ subscripts and $j$ superscripts represent the number of hydroxo bridges and oxo functionalities respectively. The accumulation was carried out at a frequency of $79.49 \mathrm{MHz}$, with a pulse duration of $8 \mathrm{~ms}$ and a spectral width of $32,051 \mathrm{ppm}$ for 30,000 scans. The chemical shifts were referenced against tetramethylsilane (TMS) as an external reference. Line broadening of $10 \mathrm{~Hz}$ was used for free induction decay processing. Each recorded spectrum is an average of all spectra obtained during the instrument acquisition time.

\subsubsection{Standardization of curing temperature by thermogravimetric analysis (TGA)}

Optimum curing temperatures and times for the sol-gel were determined by TGA using a Shimadzu DTG 60 instrument. The experiment was carried out under a nitrogen flow of $40 \mathrm{ml} \mathrm{min}^{-1}$ at $5{ }^{\circ} \mathrm{C}$ intervals between 35 and $70^{\circ} \mathrm{C}$ at a ramp rate of $10^{\circ} \mathrm{C} \mathrm{min}^{-1}$ from ambient temperatures. Aluminium pans containing standard volumes of the different sol-gel samples were analysed at different time and temperature combinations. The shape and position of the peak maximum were related to the presence of solvent within the sample and were, therefore, a reliable parameter for comparing the different sol-gel.

\subsubsection{Standardization of coating curing time and volume}

The metal doped MTEOS sol-gels (50, 100, 150 and $200 \mu \mathrm{l}$ volumes) were dispensed into a 96-well microtitre plate and cured at the TGA-determined optimum temperature. Undoped MTEOS sol-gel was the control. The microtitre plate was examined visually after $8,12,24,48,72$ and $96 \mathrm{~h}$ in the oven.

\subsection{Physical evaluation of sol-gel coatings}

Sol-gel solutions were spin coated onto pre-cleaned $5 \mathrm{~cm} \times 5 \mathrm{~cm}$ glass slides at up to $1000 \mathrm{rpm}$, cured at $70^{\circ} \mathrm{C}$ for $24 \mathrm{~h}$ and stored at $4{ }^{\circ} \mathrm{C}$ prior to XPS analysis, contact angle measurement and leaching studies.

\subsubsection{Surface study by XPS}

Compositional XPS analysis of the sol-gel coating surfaces (top $10 \mathrm{~nm}$ ) employed an ESCALAB Mk II spectrometer equipped with a twin anode X-ray source. The system consisted of a Vacuum Generator (VG) CLAM electron energy analyser operating at a pass energy of $20 \mathrm{eV}$, yielding an overall resolution of $1.2 \mathrm{eV}$. High voltage (10-15 keV) cathodes bombard the $\mathrm{Mg}$ and $\mathrm{Al}$ sources with high energy electrons thereby forcing X-rays to be emitted at peak intensities from the respective sources $(\mathrm{Mg} \mathrm{K} \alpha=1253.6 \mathrm{eV}$ and $\mathrm{Al}$ $\mathrm{K} \alpha=1486.6 \mathrm{eV}$ ). All spectrum binding energies were referenced to the hydrocarbon $\mathrm{C} 1 \mathrm{~s}$ peak at $285 \mathrm{eV}$ to correct for electrostatic charging effects during acquisition. Sample mounting for XPS analysis was achieved by fixing a specimen to a VG sample stub using double sided adhesive tape (carbon pad sticker).

\subsubsection{Contact angle measurements}

The wettability of the coated surface was estimated using a First Ten Angstroms (FTÅ, US) surface energy analyser. A water drop of defined volume was placed on the sample surface in the horizontal position. The drop formation and final shape were recorded with a high speed camera and the image processed by computer. Drop shape was evaluated in terms of the contact angle between the substrate surface and a tangent from the edge to the contour of the drop. Angles $<90^{\circ} \mathrm{C}$ indicate a hydrophilic surface while values $>90^{\circ} \mathrm{C}$ indicate a hydrophobic surface. All experiments were carried out in triplicate and the mean values reported.

\subsubsection{ICP-AES study of metal ion release rates}

The release rate of the metal ions from the sol-gel coatings into sterile de-ionised water was analysed by ICP-AES (Varian Liberty 150). Plastic wells were attached to the surface of each sol-gel coating (1\% of $\mathrm{Ag}, \mathrm{Cu}$ and $\mathrm{Zn}$ ) using an epoxy fixative (Araldite, Huntsman (UK)) and left for $24 \mathrm{~h}$. Water $(5 \mathrm{ml}$ ) was added to the wells and was removed and replaced with fresh water aliquots after $1,4,8,12,16,20$ and $24 \mathrm{~h}$. All leachates were stored at $4{ }^{\circ} \mathrm{C}$ prior to pooling and acidification with nitric acid $(0.1 \mathrm{M})$ for analysis as a single batch by ICP-AES, using stock metal standard solutions for calibration purposes.

\subsection{Antibacterial assay}

\subsubsection{Bacterial strains and growth conditions}

Bacterial strains used in this study included Gram-positive [S. aureus ATCC 25923 and Staphylococcus epidermidis CSF 41498 MRSA ATCC 43300], Gram-negative [E. coli ATCC 25922] and clinical isolates of multi-drug resistant (MDR) (ampicillin, gentamicin and ceftazidine) Enterobacter Cloacae WT6 and meropenem-resistant Pseudomonas aeruginosa WT2. These species are of public health 
concern worldwide and are responsible for many healthcareassociated infections [12]. All cultures were grown, sub-cultured and maintained on Mueller-Hinton agar (LAB M) and stored at $4{ }^{\circ} \mathrm{C}$. For the experiment, a single colony of each organism was inoculated into Mueller-Hinton broth (MHB, $10 \mathrm{ml}$ ) and incubated overnight ( $24 \mathrm{~h}$ ) at $37^{\circ} \mathrm{C}$ with shaking at $200 \mathrm{rpm}$. The optical density (OD) of the overnight culture was adjusted to that of a 0.5 McFarland standard $\left(1.5 \times 10^{8} \mathrm{CFU} \mathrm{ml}^{-1}\right)$ using a Densimat photometer (BioMerieux, France) and diluted with sterile MHB to give a final working concentration of $1 \times 10^{6} \mathrm{CFU} \mathrm{ml}^{-1}$.

\subsubsection{Assessment of antibacterial activity of metal doped sol-gel coated microtitre wells}

The antibacterial activity of the metal doped sol-gel coatings were assessed against the test organisms using a microtitre plate method [13]. Test bacteria ( $100 \mu \mathrm{l})$ from the $10^{6} \mathrm{CFU} \mathrm{ml}^{-1}$ suspensions were added to metal doped sol-gel coated wells. Control wells containing the respective cured metal doped MTEOS sol-gel with sterile MHB $(100 \mu \mathrm{l})$ and the MTEOS undoped sol-gel with bacterial suspension $(100 \mu \mathrm{l})$ were included in each assay. The microtitre plates were incubated for $24 \mathrm{~h}$ in a microtitre plate reader (Powerwave Microplate Spectrophotometer, Biotek, USA) at $37^{\circ} \mathrm{C}$.

\subsubsection{Determination of minimum incorporated inhibitory concentration (MIIC) and minimum incorporated bactericidal concentration (MIBC)}

The coating with the lowest metal concentration that completely inhibited bacterial growth after $24 \mathrm{~h}$ incubation at $37^{\circ} \mathrm{C}$ was considered the MIIC. The antibacterial activities of the different coatings were determined by calculating the percentage growth inhibition. MIBC was determined by the modified imprint method [14], where well contents $(10 \mu \mathrm{l})$ were subcultured onto MHA plates. The MIBC was the lowest concentration that produced no visible bacterial growth on the MHA plate (after $24 \mathrm{~h}$ at $37^{\circ} \mathrm{C}$ ) indicating a $99.5 \%$ kill of the original inoculum. All experiments were performed in triplicate and repeated at least twice.

\subsubsection{Kinetic measurement of bacterial growth}

Bacterial growth in the sol-gel coated wells was monitored by optical density measurements at $600 \mathrm{~nm}\left(\mathrm{OD}_{600}\right)$ over $24 \mathrm{~h}$ at $30 \mathrm{~min}$ intervals following a $30 \mathrm{~s}$ agitation step using the micro plate spectrophotometer. Growth curves of the test organisms were analysed graphically as a plot of $\mathrm{OD}_{600}$ versus contact time.

\subsubsection{Biofilm growth on coated glass slide}

The ability of metal-based coatings to prevent biofilm growth by $S$. epidermidis (CSF 41498) was assessed using scanning electron microscopy. Glass slides $\left(1 \mathrm{~cm}^{2}\right)$ were coated with the metal-doped or metal-free sol-gel and placed in a small Petri dish. S. epidermidis ( $5 \mathrm{ml}$ of $10^{6} \mathrm{CFU} \mathrm{ml}{ }^{-1}$ suspension) was added. After incubation of the dish for 3 days at $37^{\circ} \mathrm{C}$, the glass slides were removed, rinsed twice with sterile water, mounted on a stub and sputter coated with gold for SEM imaging at $12 \mathrm{KeV}$. Samples were kept at $4{ }^{\circ} \mathrm{C}$ prior to analysis.

\section{Results and discussion}

\subsection{Metal doped sol-gel solution}

\subsection{1. ${ }^{29}$ Si Nuclear magnetic resonance (NMR) spectroscopy of metal doped sol-gel solution}

The chemical interaction between metal dopants and the sol-gel matrix was analysed by ${ }^{29} \mathrm{Si}$ NMR to identify any structural variation in the sol-gel network formed. The NMR spectrum of the pure MTEOS precursor (Fig. 1) shows a single $T_{0}^{0}$ peak located at -44.03 ppm confirming the absence of any hydrolysed or modified

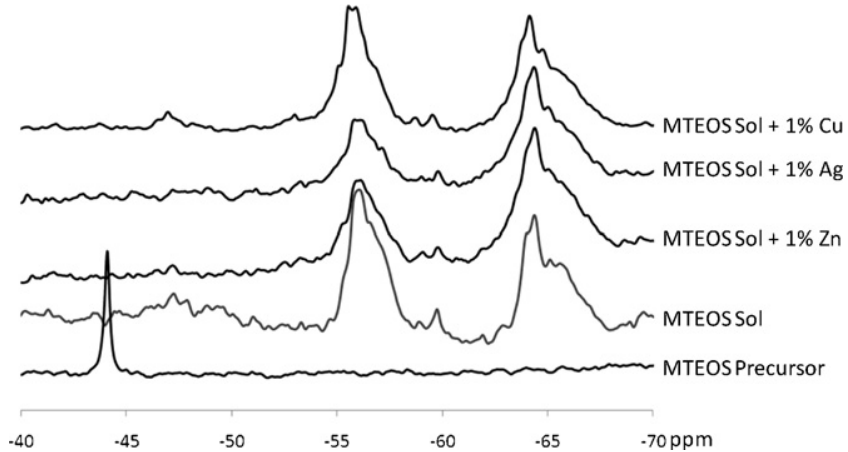

Fig. 1. NMR spectra of precursor-MTEOS, MTEOS sol, MTEOS sol with $1 \%$ Zn, MTEOS sol with $1 \% \mathrm{Ag}$, MTEOS sol with $1 \% \mathrm{Cu}$.

species. The control spectrum (MTEOS sol) shows the disappearance of the initial $T_{0}^{0}$ group observed in the precursor coupled with the appearance of 4 bands located around $-47.22,-59.39,-55.83$ and $-64.35 \mathrm{ppm}$ in the typical $T_{1}^{0}, T_{2}^{0}, T_{2}^{1}$ and $T_{3}^{0}$ regions respectively [15]. These bands are actually composed of several peaks indicating different degrees of hydrolysis for the silicon atom in each configuration, as summarised in Table 1 . This demonstrates that the molecular system is composed of a mixture of oligomers of $T_{1}, T_{2}$ and $T_{3}$.

The Ag doped sol-gel solution spectrum indicates the presence of $T_{2}^{1}(-55.83)$ and $T_{3}^{0}(-64.35)$ species. The ${ }^{29} \mathrm{Si}$ NMR spectra of the corresponding MTEOS $+\mathrm{Zn}$ and MTEOS + Cu sol-gel show peaks similar to the MTEOS sol. Sol-gel formation is accompanied by an increase in siloxane bond signal, which was observed by an increase in $T_{3}^{0}$ species concentration and the disappearance of $T_{2}^{1}$ and $T_{1}^{1}$ species due to silanol groups.

Organic-inorganic hybrid material can be formed in two different ways, based on the type of bonds established between the organic and inorganic components. A network of both organic and inorganic compounds bonded through strong covalent or ioncovalent chemical bonds may be formed [16]. Alternatively organic molecules, oligomers or low molecular weight organic polymers may simply become embedded in the inorganic matrices. There were no significant differences between the spectra of the metal doped MTEOS sol-gel and the corresponding control (Fig. 1) which indicates they were primarily of the second type, although the relative $T_{2}$ signal intensities of the MTEOS $+\mathrm{Ag}$ and MTEOS $+\mathrm{Zn}$ peaks indicate the presence of some weak metal-silane interactions [17]. These results imply the metal species are entrapped within the silane matrix, with some weak chemical bonding in the case of silver and copper.

\subsubsection{Thermal analysis}

Thermogravimetric analysis (TGA) is used to determine the sample weight change in a material in a controlled environment as a function of temperature and time. Synthesised organic-inorganic (sol-gel) suspensions contain large amounts of water and solvent. In the present study, TGA was used to estimate the optimum drying temperature of the sol-gel coatings.

There were weight losses after treatment at various temperatures over time. At the lower temperatures $\left(35-40^{\circ} \mathrm{C}\right)$ a gradual decrease in the weight loss was observed until 25 min whereas at higher temperatures $\left(45-70^{\circ} \mathrm{C}\right)$ full weight loss was achieved by $15 \mathrm{~min}$. At the higher temperature the sol-gel dried faster than at the lower temperature and a thermal treatment of the gels at $50-70^{\circ} \mathrm{C}$ was high enough to allow the evaporation of water, organic solvents and other moisture contents. Crucially this temperature range is below the softening (deformation) temperature of the polypropylene microtitre plates and, therefore, was chosen 
Table 1

Assignments of ${ }^{29}$ Si NMR signals for monomeric and oligomeric species obtained from the metal doped MTEOS sol-gel [15].

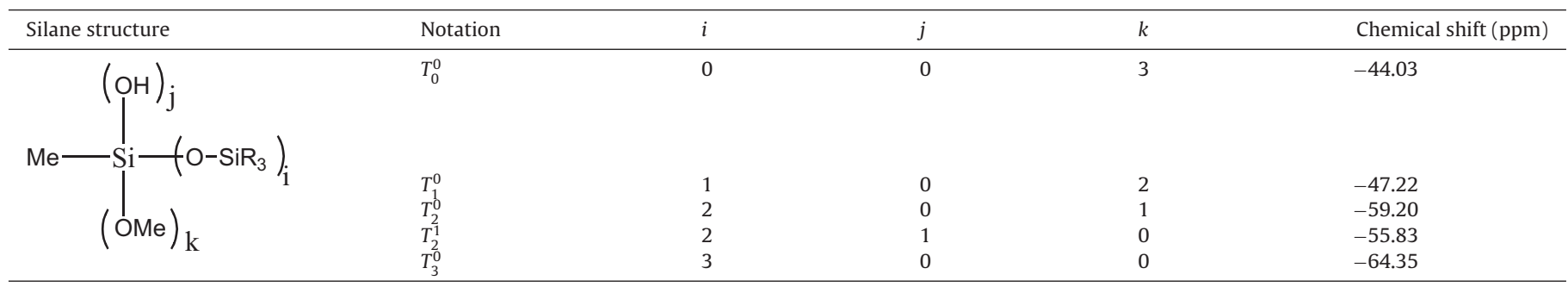
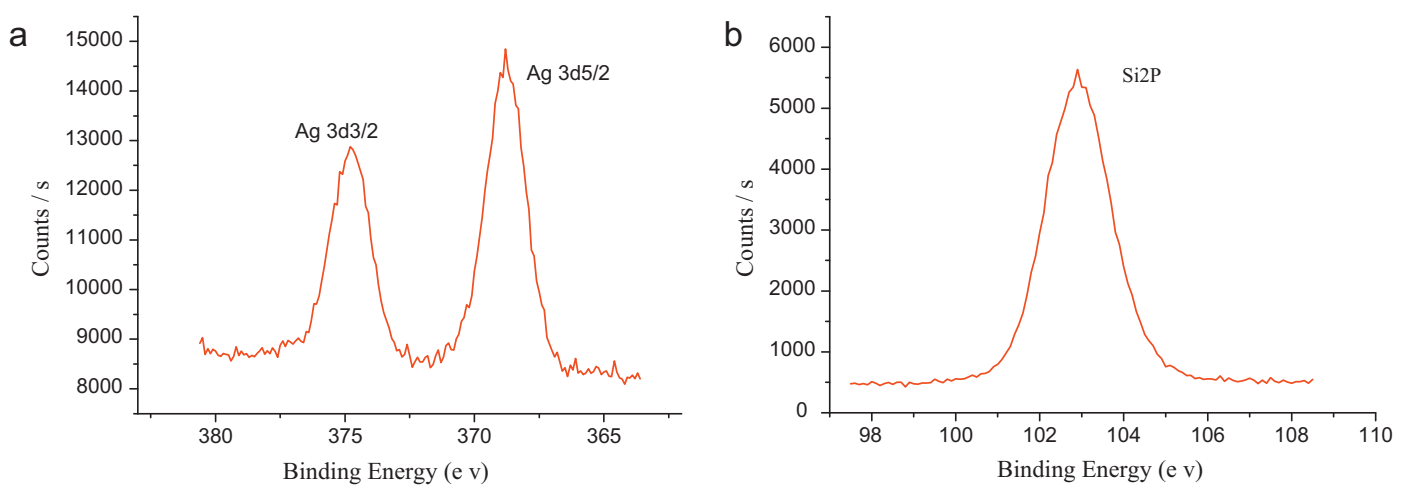

Fig. 2. XPS surface spectrum of (a) Ag 3d of silver-doped sol-gel and (b) Si 2p peak of methyl triethoxysilane (MTEOS) coating.

as the curing temperature of the sol-gel. However, since a full curing temperature can be in excess of $100^{\circ} \mathrm{C}$ complete condensation of the final silicate structure will not have occurred at $50-70^{\circ} \mathrm{C}$. This means the coating is still porous and allows the release of the metal ions.

\subsection{Metal-doped sol-gel film on glass slide}

\subsubsection{Contact angle measurement on coated glass slides}

The surface properties (hydrophobicity or hydrophilicity) of the coatings were analysed by contact angle measurements. In biological systems, the interaction between bacteria and surfaces is governed by hydrophobic interactions. Hydrophobic coatings may inhibit certain microbial interactions with the surface [18].

The contact angles of the sol-gel coated glass slides indicate that the metal doped surfaces were more hydrophobic when compared to the MTEOS control (Table 2). There was no discrimination between the contact angles of the different metal doped sol-gel coatings indicating no differences in hydrophobicity. This suggests that the increase in contact angle may be due to the common nitrate ion present, promoting a more dense surface structure.

\subsubsection{Surface study by XPS}

The chemical state of the metals ( $\mathrm{Ag}, \mathrm{Zn}$, and $\mathrm{Cu})$ at the sol-gel coated glass slide surface was analysed by XPS. This is a useful analytical tool in bioengineering for determining the chemical state of specific functional groups in the uppermost $10 \mathrm{~nm}$ of a surface coating [19]. The presence of silver in the surface coating was confirmed by the presence of the peak at $368.2 \mathrm{eV}$ indicative of $\mathrm{Ag}^{0}$,

Table 2

Contact angle of MTEOS (Control) and $\mathrm{Ag}, \mathrm{Zn}$ and $\mathrm{Cu}$ doped sol-gel coatings.

\begin{tabular}{lc}
\hline Sol-gel coating & Contact angle \\
\hline MTEOS (control) & $90.34^{\circ}$ \\
Ag-MTEOS & $104.53^{\circ}$ \\
Zn-MTEOS & $102.35^{\circ}$ \\
Cu-MTEOS & $103.78^{\circ}$ \\
\hline
\end{tabular}

most likely in a nanoparticle form (Fig. 2a) [20]. Due to the low curing temperature used and the absence of the characteristic yellow (plasmon induced) colour, it is likely that the nanoparticles are below $50 \mathrm{~nm}$ in size. This agrees with previous work on silver doped phenyltriethoxy silane (PhTEOS) sol-gel coatings [21]. In contrast the respective signature peaks for zinc and copper were not detected suggesting they may be in their oxide form, $\mathrm{CuO}$ and $\mathrm{ZnO}$ respectively. As expected peaks corresponding to the $\mathrm{Si} 2 \mathrm{p}$ electrons with binding energies of $102.8 \mathrm{eV}$ were observed (Fig. 2b). This is consistent with previous reports on silver-doped silica films, indicating ionic network formation analogous to soda glass [22].

\subsubsection{Evaluation of metal ion release rate}

For coatings on biomedical devices, high initial release rates of antibacterial agents are desirable to deter biofilm establishment. Previous studies have shown that when silver salts are incorporated into sol-gel coatings a high initial release of silver ions is followed by a more gradual and sustained release profile [19]. Ion release from such biomaterials is governed by (a) the amount of available surface metal, (b) the area of the exposed coating, (c) the degree of hydrophobicity of the coating inter-face, and (d) the volume of the contact fluid [23]. The release of silver, copper and zinc at $1 \%$ (w/w) loadings into de-ionised water over a $24 \mathrm{~h}$ period at $37^{\circ} \mathrm{C}$ is presented in Fig. 3. During the first hour, approximately 50, 35 and $28 \mathrm{ppm} \mathrm{m}^{-2}$ of $\mathrm{Ag}^{+}, \mathrm{Zn}^{2+}$ and $\mathrm{Cu}^{2+}$ ions were released respectively. This was followed by a lower sustained release profile for $24 \mathrm{~h}$ ( 6 exposure cycles), indicating that antibacterial activity can be maintained after repeated challenges. The variability between elution profiles is probably due to the chemical state of the metals in the coatings. As the silver is most likely in nanoparticulate form, its release would be more rapid than that of copper and zinc in their more stable oxide forms. An initial high release of a broad spectrum antibacterial agent is desirable (Fig. 4) as the first $6 \mathrm{~h}$ after device implantation is critical in bacterial colonisation.

Low temperature processing maintains silver in the upper (surface) regions of the sol-gel derived coatings, enhancing the release of biocidal silver ions into the surrounding medium [21]. High 


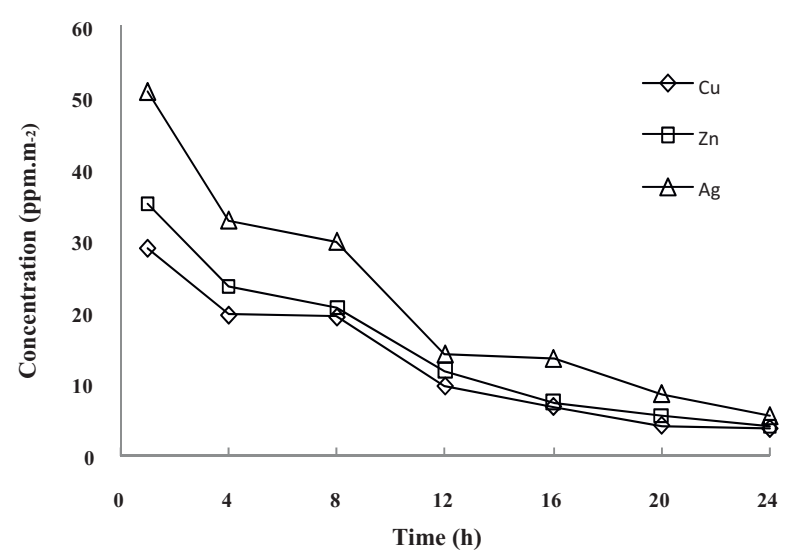

Fig. 3. Non-cumulative release rates of $\mathrm{Ag}, \mathrm{Zn}$ and $\mathrm{Cu}$ into fresh $\mathrm{DiH}_{2} \mathrm{O}$ from Ag:MTEOS, Zn:MTEOS, Cu:MTEOS coatings (determined by ICP emission spectrometer).

temperature processing of silver doped sol-gel systems can lead to diffusion of silver away from the surface into the coating bulk.

\subsection{Antibacterial assay}

\subsubsection{Microtitre well coated proliferation assay}

The antibacterial activities (MIICs and MIBCs) of the coatings (blank, $\mathrm{Ag}^{+}, \mathrm{Zn}^{2+}$ and $\mathrm{Cu}^{2+}$ ) against Gram-positive and Gramnegative bacteria were determined (Table 3). The MIIC for the $\mathrm{Ag}^{+}$ coating against $P$. aeruginosa WT2, Enterobacter WT6 and $E$. coli was $0.5 \%(\mathrm{w} / \mathrm{w})$. The MIBC results were identical. In contrast, the MIICs of the $\mathrm{Cu}^{2+}$ coatings were lower than those of $\mathrm{Zn}^{2+}$ against the Gram-negative bacteria tested (Table 2). MIIC values against Grampositive, S. aureus and MRSA, displayed a similar trend, namely $\mathrm{Ag}>\mathrm{Zn}>\mathrm{Cu}$. Generally, the MIBC and MIIC for each tested strain was the same.

3.3.1.1. Time dependent study. Fig. 4 shows the time dependent inhibitory effect of the various coatings $(0.7,0.5$ and $0.3 \%(w / w)$ of $\mathrm{Ag}^{+} \mathrm{Cu}^{2+}$ and $\mathrm{Zn}^{2+}$ respectively) on E. coli and S. aureus. Bacteria in the control wells, coated with the undoped sol-gel showed a rapid growth with a short lag phase of $2 \mathrm{~h}$. The incorporation of different metal concentrations resulted in variable levels of inhibition in bacterial growth resulting in prolonged lag phases and lower overall growth at $24 \mathrm{~h}$. E. coli had the longest lag phase $(15 \mathrm{~h})$ in the $\mathrm{Ag}^{+}$coated wells followed by $\mathrm{Zn}^{2+}(5 \mathrm{~h})$ and $\mathrm{Cu}^{2+}(4 \mathrm{~h})$ at sub MIIC values $(0.3 \%, 0.5 \%, 0.5 \%(\mathrm{w} / \mathrm{w})$ respectively).

In the case of Gram-positive bacteria $S$. aureus at the lower dose of $0.3 \%(w / w)$, there was no growth and therefore no lag phase for $\mathrm{Ag}^{+}$, while $\mathrm{Zn}^{2+}$ and $\mathrm{Cu}^{2+}$ delayed growth for 10 and $5 \mathrm{~h}$ at sub MIIC values of $0.5 \%$ and $0.7 \%(\mathrm{w} / \mathrm{w})$ respectively. The antibacterial properties of the metal doped sol-gel layer on the microtitre well surfaces may be attributed to the mutual attraction, potentially via electrostatic forces, of the negatively charged bacteria to the siloxane surface, where the positive charged metal ions released kill the bacteria or hinder their replication mechanisms [24]. The results showed the $\mathrm{Ag}^{+}$doped sol-gel coatings to have a consistently higher antibacterial activity against all the test bacteria followed by $\mathrm{Zn}^{2+}$ and $\mathrm{Cu}^{2+}$. The higher killing rate of the $\mathrm{Ag}^{+}$sol-gel coating is due to a combination of a greater potency and a higher release of the ion from the enriched surface, as proven by the XPS data. Silver doped materials can be chemically durable and release silver ions over extended periods of time [25]. In combination with the higher efficacy of $\mathrm{Ag}^{+}$and the surface enrichment, it is important to note that the lower loading levels were still more effective than the higher $\mathrm{Zn}^{2+}$ and $\mathrm{Cu}^{2+}$ equivalents.

\subsubsection{Biofilm growth on coated glass slide}

In biomedical and implant-device coatings, the biomaterial surface chemistry is a key factor that influences initial bacterial attachment. Biofilm formation is a multi-factorial process involving the adhesion of bacterial cells to a host substrate, followed by multiplication. S. epidermidis is the most frequently isolated bacterium from implant device-related infections, as it colonises surfaces resulting in biofilm formation [26]. Silver ions have recently been reported to destabilise biofilms [27]. Silver-impregnated catheters have demonstrated superior inhibition of bacterial colonisation than antibiotic-impregnated catheters [28].
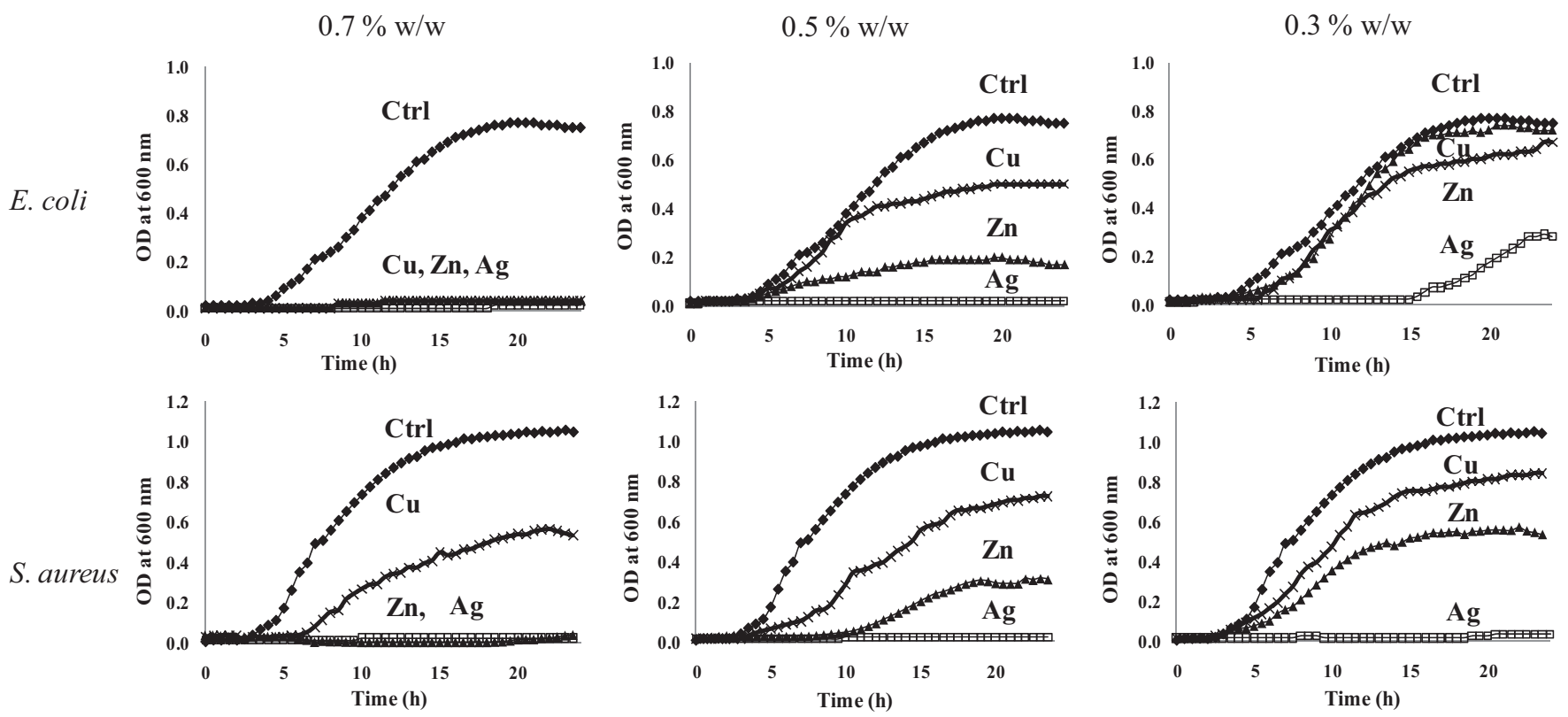

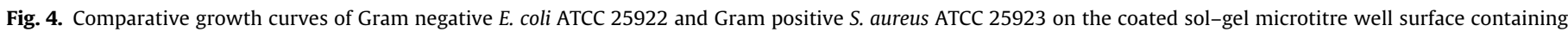

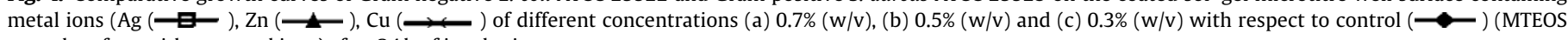
coated surface without metal ions) after $24 \mathrm{~h}$ of incubation. 
Table 3

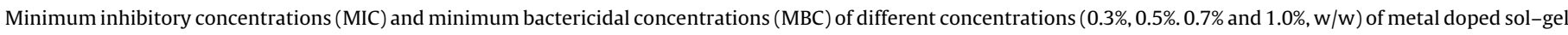
(Ag-MTEOS, Zn-MTEOS and Cu-MTEOS) against Gram-positive and Gram-negative bacteria.

\begin{tabular}{|c|c|c|c|c|}
\hline & Samples (metal doped sol-gel) & Organisms & $\operatorname{MIC}(\%, \mathrm{w} / \mathrm{w})$ & $\operatorname{MBC}(\%, w / w)$ \\
\hline \multirow[t]{9}{*}{ Gram-positive } & $\mathrm{Ag}$ & S. aureus ATCC 25923 & 0.5 & 0.5 \\
\hline & $\mathrm{Zn}$ & & 0.7 & 0.7 \\
\hline & $\mathrm{Cu}$ & & $>1$ & $>1$ \\
\hline & $\mathrm{Ag}$ & S. epidermidis CSF & 0.7 & 0.7 \\
\hline & $\mathrm{Zn}$ & 41498 & 1 & 1 \\
\hline & $\mathrm{Cu}$ & & 1 & 1 \\
\hline & $\mathrm{Ag}$ & MRSA ATCC 43300 & 0.3 & 0.7 \\
\hline & $\mathrm{Zn}$ & & $>1$ & $>1$ \\
\hline & $\mathrm{Cu}$ & & $>1$ & $>1$ \\
\hline \multirow[t]{9}{*}{ Gram-negative } & $\mathrm{Ag}$ & Meropenem & 0.5 & 0.5 \\
\hline & $\mathrm{Zn}$ & resistant $P$. & 0.7 & 1 \\
\hline & $\mathrm{Cu}$ & aeruginosa WT2 & $>1$ & $>1$ \\
\hline & $\mathrm{Ag}$ & Multi drug resistant & 0.5 & 0.3 \\
\hline & $\mathrm{Zn}$ & Enterobacter WT6 & 1 & 1 \\
\hline & $\mathrm{Cu}$ & & $>1$ & $>1$ \\
\hline & $\mathrm{Ag}$ & E. coli ATCC 25922 & 0.5 & 0.5 \\
\hline & $\mathrm{Zn}$ & & 0.7 & 0.7 \\
\hline & $\mathrm{Cu}$ & & 0.7 & 0.7 \\
\hline
\end{tabular}

The antibacterial effect of metal ion release on the sol-gel surface is shown in the SEM images in Fig. 5. After exposure to $S$. epidermidis the blank undoped MTEOS-coated glass slides were covered in adherent bacterial deposits, with fully formed bacteria observed (Fig. 5a). Silver ion release from the silver doped MTEOS (Fig. 5b) reduced colonisation of the coating. There was evidence of bacterial lysis. A similar effect was observed for microbial deposits on the zinc doped coatings (Fig. 5c), while some bacterial colonisation was observed on the copper doped coatings (Fig. 5d).
The broad spectrum antibacterial activity of these metal coatings suggests they would be useful in preventing environmental contamination on surfaces such as door plates and handles, light switches, and hand and bedside rails in healthcare environments. This is important as patients and staff colonised or infected with healthcare and community associated microorganisms may transfer them onto such fomites found in hospitals, nursing homes, childcare facilities, prisons and public transport [29]. Additionally as silver ion release is governed by water diffusion through the coating [30] then the use of water alone as a cleaning agent, in the
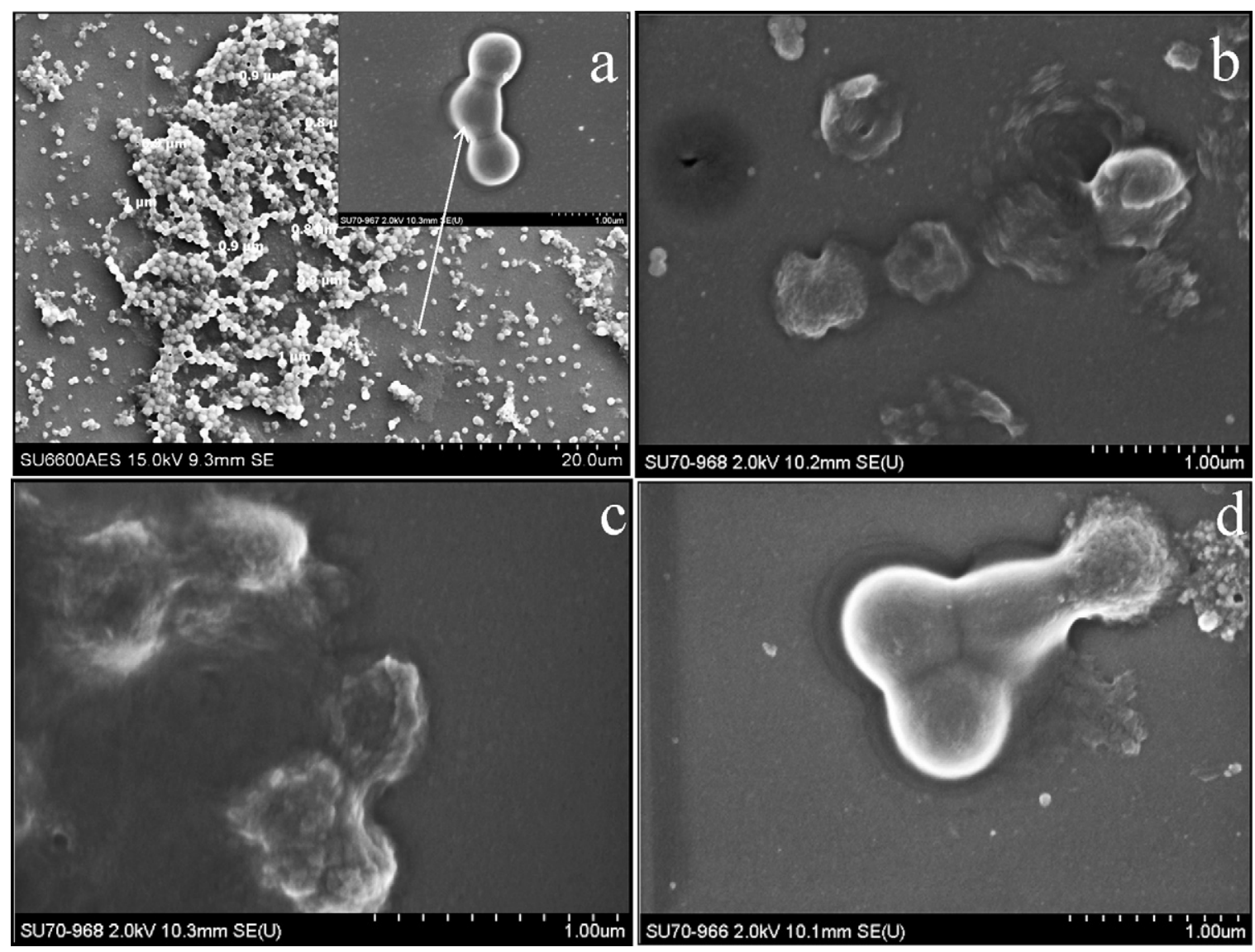

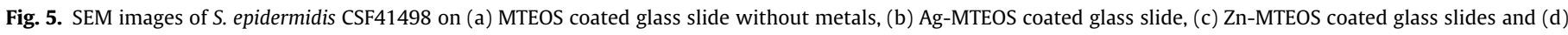
Cu-MTEOS coated glass slides, with all MIBC level of metals. 
absence of standard antiseptics and detergents, may be sufficient to generate enhanced bioactive surfaces.

\section{Conclusion}

The increasing incidence the healthcare-associated antibioticresistant pathogens has stimulated the search for novel agents to combat them. A method to rapidly assess the activity of antibacterial agent-impregnated coated surfaces against a number of organisms is demonstrated here. The microtitre well coating method is less laborious and more cost effective than conventional methods. It was used for preliminary antibacterial screening of different concentrations of metal ion $\left(\mathrm{Ag}^{+}, \mathrm{Zn}^{2+}\right.$, and $\left.\mathrm{Cu}^{2+}\right)$ doped sol-gel. The release rates and antibacterial activities of the doped sol-gel were in the order of $\mathrm{Ag}^{+}>\mathrm{Zn}^{2+}>\mathrm{Cu}^{2+}$. XPS measurements confirmed the presence of surface Ag whereas no detectable levels of $\mathrm{Zn}$ and $\mathrm{Cu}$ were observed on the corresponding coated glass slide surface. The release of $\mathrm{Ag}^{+}$from the sol-gel coating inhibited the development of a $S$. epidermidis biofilm over a $72 \mathrm{~h}$ period. As the first $6 \mathrm{~h}$ are considered critical after device insertion, an initial high release of $\mathrm{Ag}^{+}$compared to $\mathrm{Zn}^{2+}$ and $\mathrm{Cu}^{2+}$ is beneficial for reducing bacterial adhesion. The results of this work indicate that silver release coatings are more suitable for the protection of various surfaces against bacterial infection than zinc and copper equivalents.

\section{Acknowledgements}

The authors would like to gratefully acknowledge Dr. Rosaria Leyden, Ms. Emer Ryan and Ms Aisling Kirwan. The authors would also like to acknowledge the Dublin Institute of Technology, Dublin, Ireland for funding under the ABBEST scholarship programme.

\section{References}

[1] A.M. Schrand, M.F. Rahman, S.M. Hussain, J.J. Schlager, D.A. Smith, A.F. Syed, Nanomed. Nanobiotechnol. 2 (2010) 544-568.

[2] G. Gosheger, J. Hardes, H. Ahrens, A. Streitburger, H. Buerger, M. Erren, A. Gunsel, F.H. Kemper, W. Winkelmann, C. Von Eiff, Biomaterials 25 (2004) 5547-5556.
[3] M.E. Rupp, T. Fitzgerald, N. Marion, V. Helget, S. Puumala, J.R. Anderson, P.D. Fey, Am. J. Infect. Control 32 (2004) 445-450.

[4] H.J. Lee, S.H. Jeong, Text. Res. J. 75 (2005) 551-556.

[5] G. Grass, C. Rensing, M. Solioz, Appl. Environ. Microbiol. 77 (2011) 1541-1547.

[6] C.E. Santo, N. Taudte, D.H. Nies, G. Grass, Appl. Environ. Microbiol. 74 (2008) 977-986.

[7] S.A. Wilks, H. Michels, C.W. Keevil, Int. J. Food Microbiol. 105 (2005) 445-454

[8] J.O. Noyce, H. Michels, C.W. Keevil, J. Hosp. Infect. 63 (2006) 289-297.

[9] J.J. Morrier, G. Suchett-Kaye, D. Nguyen, J.P. Rocca, J. Blanc-Benon, O. Barsotti, Dent. Mater. 14 (1998) 150-157.

[10] J.E. Gray, P.R. Norton, R. Alnouno, C.L. Marolda, M.A. Valvano, K. Griffiths, Biomaterials 24 (2003) 2759-2765.

[11] M. Marini, M. Bondi, R. Iseppi, M. Toselli, F. Pilati, Eur. Polym. J. 43 (2007) 3621-3628.

[12] Y. Li, P. Leung, L. Yao, Q.W. Song, E. Newton, J. Hosp. Infect. 62 (2006) 58-63.

[13] S. Jaiswal, B. Duffy, A.K. Jaiswal, N. Stobie, P. McHale, Int. J. Antimicrob. Agents 36 (2010) 280-283.

[14] A. Panáček, L. Kvítek, R. Prucek, M. Kolář, R. Večeřová, N. Pizúrová, V.K. Sharma, T. Nevecna, R. Zboril, J. Phys. Chem. B 110 (2006) 16248-16253.

[15] A. Jitianu, A. Britchi, C. Deleanu, V. Badescu, M. Zaharescu, J. Non-Cryst. Solids 319 (2003) 263-279.

[16] C. Sanchez, G.J.d.A.A. Soler-Illia, F. Ribot, T. Lalot, C.R. Mayer, V. Cabuil, Chem. Mater. 13 (2001) 3061-3083.

[17] K.H. Wu, C.I. Liu, C.C. Yang, G.P. Wang, C.M. Chao, Mater. Chem. Phys. 125 (2011) 802-806.

[18] N. Cerca, G.B. Pier, M. Vilanova, R. Oliveira, J. Azeredo, Res. Microbiol. 156 (2005) 506-514.

[19] N. Stobie, B. Duffy, S.J. Hinder, P. McHale, D.E. McCormack, Colloids Surf. B 72 (2009) 62-67.

[20] W. Li, S. Seal, E. Megan, J. Ramsdell, K. Scammon, G. Lelong, L. Lachal, K.A. Richardson, J. Appl. Phys. 93 (2003) 9553-9561.

[21] N. Stobie, B. Duffy, D.E. McCormack, J. Colreavy, M. Hidalgo, P. McHale, S.J. Hinder, Biomaterials 29 (2008) 963-969.

[22] A. Babapour, O. Akhavan, R. Azimirad, A.Z. Moshfeghi, Nanotechnology 17 (2006) 763-771.

[23] E.M. Hetrick, M.H. Schoenfisch, Chem. Soc. Rev. 35 (2006) 780-789.

[24] V. Sambhy, M.M. MacBride, B.R. Peterson, A. Sen, J. Am. Chem. Soc. 128 (2006) 9798-9808.

[25] F. Furno, K.S. Morley, B. Wong, B.L. Sharp, P.L. Arnold, S.M. Howdle, R. Bayston P.D. Brown, P.D. Winship, H.J. Reid, J. Antimicrob. Chemother. 54 (2004) 1019-1024.

[26] D. Roe, B. Karandikar, N. Bonn-Savage, B. Gibbins, J.-B. Roullet, J. Antimicrob. Chemother. 61 (2008) 869-876.

[27] N. Stobie, B. Duffy, J. Colreavy, P. McHale, S.J. Hinder, D.E. McCormack, J. Colloid Interface Sci. 345 (2010) 286-292.

[28] K. Galiano, C. Pleifer, K. Engelhardt, G. Brössner, P. Lackner, C. Huck, C. Lass-Flörl, A. Obwegeser, Neurol. Res. 30 (2008) 285-287.

[29] B. Eckstein, D. Adams, E. Eckstein, A. Rao, A. Sethi, G. Yadavalli, C. Donskey, BMC Infect. Dis. 7 (2007) 61-66.

[30] R. Kumar, H. Münstedt, Polym. Int. 54 (2005) 1180-1186. 